\title{
Investigations on Corrosion Behaviour of WC-CrC-Ni Coatings Deposited by HVOF Thermal Spraying Process
}

\author{
Alin Constantin MURARIU ${ }^{1, *}$, Nicoleta PLEŞU ${ }^{2}$, Ion Aurel PERIANU ${ }^{1}$, \\ Milica TAR $\breve{A}-L U N G \breve{A}-M I H A L I^{2}$ \\ ${ }^{1}$ National R\&D Institute for Welding and Material Testing - ISIM Timisoara, 30 Mihai Viteazul Blv. \\ 300222 Timisoara, Romania \\ ${ }^{2}$ Romanian Academy, Institute of Chemistry, Timisoara, 24 Mihai Viteazul Blv. \\ 300223 Timisoara, Romania \\ *E-mail: alin@isim.ro
}

doi: $10.20964 / 2017.02 .60$

Received: 22 November 2016 / Accepted: 24 December 2016 / Published: 30 December 2016

The paper presents investigations performed on $\mathrm{WC}-\mathrm{CrC}-\mathrm{Ni}$ coatings, deposited by High Velocity Oxygen Fuel (HVOF) thermal spraying, in order to assess the corrosion behaviour of coatings obtained using WOKA 7504 powder. Mechanical tests, structural and electrochemical analyses have been performed in order to determine the degree in which material composition, powder production method and technological parameters of HVOF process affect the corrosion resistance of the deposited layers. For the corrosion resistance, assessment electrochemical methods were used. Samples immersed in 3\% $\mathrm{NaCl}$ solution and open-circuit potential (OCP) method were used to examine the potential change and creation of a protective layer on the surface. The best results, in terms of corrosion resistance and adherence resistance of the coating layer, were obtained for layer thickness of 110 to $220 \mu \mathrm{m}$. It was found that surface processing, after layer deposition through HVOF process, increases the corrosion rate about 1.5 times compared to unpolished ones, as a result of the protective passivated film removal that forms on the coating layer surface or due to the possibility of additional defects inducing in the deposited layer during the surface finishing operation.

Keywords: corrosion, electrochemical test, coatings, $\mathrm{HVOF}$ thermal spray, $\mathrm{WC}-\mathrm{CrC}-\mathrm{Ni}$

\section{$\underline{\text { FULL TEXT }}$}

(C) 2017 The Authors. Published by ESG (www.electrochemsci.org). This article is an open access article distributed under the terms and conditions of the Creative Commons Attribution license (http://creativecommons.org/licenses/by/4.0/). 